\title{
The measurement of overeducation and undereducation: self-report vs. job-analyst method
}

Citation for published version (APA):

van der Velden, R. K. W., \& van Smoorenburg, M. S. M. (1997). The measurement of overeducation and undereducation: self-report vs. job-analyst method. Researchcentrum voor Onderwijs en Arbeidsmarkt, Faculteit der Economische Wetenschappen. ROA Research Memoranda No. 2E https://doi.org/10.26481/umaror.199702E

Document status and date:

Published: 01/01/1997

DOI:

10.26481/umaror.199702E

Document Version:

Publisher's PDF, also known as Version of record

\section{Please check the document version of this publication:}

- A submitted manuscript is the version of the article upon submission and before peer-review. There can be important differences between the submitted version and the official published version of record.

People interested in the research are advised to contact the author for the final version of the publication, or visit the DOI to the publisher's website.

- The final author version and the galley proof are versions of the publication after peer review.

- The final published version features the final layout of the paper including the volume, issue and page numbers.

Link to publication

\footnotetext{
General rights rights.

- You may freely distribute the URL identifying the publication in the public portal. please follow below link for the End User Agreement:

www.umlib.nl/taverne-license

Take down policy

If you believe that this document breaches copyright please contact us at:

repository@maastrichtuniversity.nl

providing details and we will investigate your claim.
}

Copyright and moral rights for the publications made accessible in the public portal are retained by the authors and/or other copyright owners and it is a condition of accessing publications that users recognise and abide by the legal requirements associated with these

- Users may download and print one copy of any publication from the public portal for the purpose of private study or research.

- You may not further distribute the material or use it for any profit-making activity or commercial gain

If the publication is distributed under the terms of Article $25 \mathrm{fa}$ of the Dutch Copyright Act, indicated by the "Taverne" license above, 
The Measurement of Overeducation and Undereducation:

Self-Report vs. Job-Analyst Method

ROA-RM-1997/2E

R.K.W. van der Velden and M.S.M. van Smoorenburg

Research Centre for Education and the Labour Market

Faculty of Economics and Business Administration

Maastricht University 
Maastricht, December 1997 
ISBN 90-5321-225-6

SEC97.164/RvdV 


\section{Contents}

Page

Abstract

1 Introduction

2 The Model

3 Data

4 Results

5 Conclusion

Literature 


\begin{abstract}
This paper investigates the criterium validity of two different methods to determine the required educational level of an occupation. The selfreport method consists of asking employees directly what the required level of education for the job is. On the other hand, in the job-analyst method the determining of the required level of education for a particular job takes place by experts.
\end{abstract}

Our analysis shows that, in essence, both methods measure the same concept (number of years of required education). However, they differ significantly with regard to the standard points, i.e. the points on the scale at which there is overeducation and undereducation. The analysis shows that the job-analyst method systematically overestimates the level of overeducation. There are no indications that the level of overeducation is underestimated in the self-report method. 


\section{Introduction}

Since the sixties, the participation in education has shown a very strong increase in all Western countries. This has resulted in a substantial rise in the average level of education of the labour force. Although there has also been an "upgrading" of the requirements on the demand side, it looks as though the latter has not been able to keep a steady pace with the increase of the level of education. ${ }^{1}$ This has led to a great deal of attention being paid to the effects of overeducation (and undereducation), if any, in economic and sociological research.

Most of these analyses concentrate on the returns to overeducation and undereducation (Duncan and Hoffmann, 1981; Hartog and Oosterbeek 1988; Cohn and Khan, 1995; Van Smoorenburg and Van der Velden, 1997). The general conclusion is that one additional year of education in excess of the required level (overeducation) will generate an extra return. However, this wage effect is less substantial than the effect of one year of required education. The wage effect of one year of undereducation is a negative one. Other studies focus on the relationship between overeducation and participation in on-the-job training (Sicherman, 1991; Groot, 1993; Barron, Black and Loewenstein, 1989), overeducation and job satisfaction (Tsang, Rumberger and Levin, 1991; Hersch, 1991) or overeducation and mobility (Dekker, De Grip and Heijke, 1997).

To determine the required level of education for a job and the degree of overeducation and undereducation, the literature distinguishes three methods. The first method pertains to job analysts determining the level of education required for a job. In US research, we can refer to the Dictionary of Occupational Titles (DOT). In the Netherlands, a similar method is used by Huijgen (1989). Halaby (1994) raises two important objections to this method. The first concerns the fact that a fixed job level is attached to a certain job. Any variation of job levels within a given occupation is not taken into account. However, variation within a given occupation with regard to educational requirements may be considerable. This particularly affects the reliability of the measurement instrument. The second objection is that the allocation of the levels is determined by job analysts. This is often done on the basis of descriptions of the tasks and the nature and required level of knowledge and skills. However, these are subject to change, which might result in a systematic overestimation or underestimation of the level of certain occupations. Furthermore, there is not always a consensus - even among experts - about the level of education required for a given occupation. This affects particularly the validity of the measurement instrument.

In the second method, workers are asked directly what they regard as the required level of education for the position they hold. In Anglo-Saxon, this is often operationalised by asking: "How much formal education is required to get a job like yours?" This method does not go uncriticised, either. The subjective character of the instrument is a point of criticism, as is the

1. Although the level of overeducation seems to have increased hardly at all over the past thirteen years (Groot en Maassen van den Brink, 1996). 
fact that respondents may not always have a good insight in the level of education required for a job (Cohn and Khan, 1995; Halaby, 1994). The resulting 'noise' affects in particular the reliability of the measurement instrument. Hartog and Jonker (1997) have pointed out that individuals may be inclined to overestimate the educational requirements or to simply equate these to their own level of education. In that case, the level of overeducation will be underestimated, which affects the validity.

The third method takes the average of the actual levels of education of those employed in a certain occupation as its basis. A limit of one standard deviation above or beneath this average is taken as a criterion for overeducation or undereducation (Clogg \& Shockey, 1984; Verdugo and Verdugo, 1989). Again, this method ignores the variation in educational requirements within an occupation, while the limit of one standard deviation would also seem rather arbitrary (Halaby, 1994). What is even more important, however, is that this method is very sensitive to changes in labour market conditions. In case of excess supply, employers will contract personnel with a higher level of education than is in fact required. In view of the fact that the match between education and occupational levels which is actually achieved constitutes the basis of the calculation of the required level of education, the level of overeducation is underestimated in case of excess supply and overestimated in case of excess demand. Hartog and Jonker (1997) therefore conclude that the method based on the realised matches is the least adequate one for determining overeducation and undereducation.

In the literature, the three methods discussed are often applied to different data sets, so that a direct comparison between the three methods is not possible. On the basis of the Panel Study of Income Dynamics, Cohn and Khan (1995) reach the conclusion that according to the second method, $33 \%$ of the workers is overeducated, whereas based on the third method, only $13 \%$ is overeducated. We have not seen any examples of studies in which the effect of the first method (the job-analyst method) has been systematically compared with the second method (the self-report).

In this article, the criterion validity of the job-analyst and self-report methods is further examined, while the third method will be ignored. The structure of the paper is as follows: in Section 2, the analysis model is presented. Section 3 provides a description of the data. Section 4 contains the results and Section 5 closes with the conclusion.

\section{The model}

In the school-leaver study which is being carried out by the Research Centre for Education and the Labour Market, information about the required level of education is available both through self-report and through the job-analyst method. The respondents were asked to state the minimum level of education which was required by the employer for the position they held. The respondents were offered a choice between the following response categories: (1) primary education (2) Preparatory Vocational Education (PVE) / Lower General Secondary Education 
(LGSE) (3) Apprenticeship / Short Intermediate Vocational Education (SIVE) (4) Higher General Secondary Education (HGSE) / Pre-University Education (PUE) (5) Intermediate Vocational Education (IVE) (6) Higher Vocational Education (HVE) (7) University Education (UE) / Higher Vocation Education (HVE), second stage. In Anglo-Saxon literature, it is customary to express the level of education in years of education. To be able to compare results, we decided to convert the Dutch school levels into years of education. The following transformation was applied both to the level of education actually attained and the level required: (1) primary education, 6 years (2) PVE/LGSE, 10 years (3) Apprenticeship /SIVE, 12 years (4) IVE/HGSE/PUE, 14 years (5) HVE, 18 years and (6) UE/HVE second stage, 20 years ${ }^{2}$

Subsequently, the number of years of overeducation and the number of years of undereducation is determined on the basis of the level of education attained (in years) and the respondents' self-reports about the level of education required. These two variables were constructed as follows. If $E$ is the actual number of years of education and $E^{r}$ is the number of years of education required for a job, the number of years of overeducation $\left(E^{\circ}\right)$ is represented by:

$E^{\circ}=E-E^{r}$ if $E>E^{r}$ and

$E^{\circ}=0 \quad$ if $E \leq E^{r}$

Parallel, the number of years of undereducation $\left(E^{u}\right)$ is determined as:

$E^{u}=E^{r}-E$ if $E^{r}>E$ and

$E^{u}=0 \quad$ if $E^{r} \leq E$

The required number of years of education, overeducation and undereducation, determined on the basis of the respondents' self-reports, are represented by $E_{s}{ }^{r}, E_{s}{ }^{\circ}$ and $E_{s}{ }^{u}$ respectively.

In addition, the level of education required for the respondents' occupation was determined on the basis of the job-analyst method. To do so, we used Huijgen's classification (1989), which attaches a level code to all the occupations listed in the Classification of Occupations of Statistics Netherlands applied in the school-leaver study. This level corresponds to the required level of education. Seven levels are distinguished, ranging from unskilled labour (level 1) to academic labour (level 7). This division into seven levels was also converted into the required number of years of education, where level 1 (unskilled) was set at 4 years, level 2 (primary education) at 6 years, level 3 (PVE/LGSE) at 10 years, level 4 (Apprenticeship) at 12 years,

2. Both the nominal length of the studies and the level of difficulty were taken into account in the transformation. The number of years required by an individual who wishes to attain a certain level of education by means of vocational education was taken as a basis. This methodology shows considerable similarities to the construction of Van der Velden's "educational ladder" (Van der Velden, 1991). 
level 5 (IVE) at 14 years, level 6 (HVE) at 18 years and level 7 (UE) at 20 years. The required level of education determined in this manner, as well as the derived criterion for overeducation and undereducation are represented by $E_{j}{ }^{r}, E_{j}{ }^{0}, E_{j}{ }^{u}$ respectively.

One of the differences between $E_{s}^{r}$ and $E_{j}{ }^{r}$ is that $E_{s}^{r}$ is determined for each function that an individual holds, whereas $E_{j}^{r}$ is a fixed value for an occupation. In view of the fact that considerable variation may occur with regard to $E^{r}$ within an occupation, the aggregation difference alone may result in a difference between $E_{s}{ }^{r}$ and $E_{j}{ }^{r}$. In order to examine the scope of this aggregation effect, the average level of education required as indicated by the respondents has also been determined per occupation (on a scale comparable to Huijgen's, i.e. from 1 to 7 ), and per occupation this average was rounded off to the nearest integer. The required level of education determined in this manner is represented by $E_{m}{ }^{r}$, while the level of overeducation and undereducation is represented by $E_{m}{ }^{\circ}$ and $E_{m}{ }^{u}$.

Subsequently, the comparison between self-report and the job-analyst method takes place in four stages. In stage 1, the two methods are subjected to a direct comparison. The level of overeducation and undereducation according to the respective methods will be examined. This can be used to determine whether the standard points of the respective methods, namely those points at which there is overeducation and undereducation, differ from one method to the other.

In the second stage, we will calculate the correlation between the two scales of the required level of education in order to determine the common variance between the two measurement instruments. This is done to see whether the two instruments measure one and the same underlying concept. It is quite possible, for instance, for the self-report method to systematically overestimate the required level of education by one year. In that case, the level of overeducation in step 1 will be lower than that according to the job-analyst method. However, the correlation between the two measurement instruments may be high indeed.

In stage 3, the criterion validity of the two instruments is examined. This stage investigates the predictive value of the two measurement instruments for a relevant criterion. Wages, being the most relevant indicator of productivity, were chosen as the criterion variable. These depend on both the number of years of education and the number of years of overeducation and undereducation (Cohn and Khan, 1995). The following wage equations were estimated, where $\mathrm{Ln} W$ is the natural logarithm of the gross hourly wages, $X$ is a vector with control variables, and $\mathrm{e}$ is the error term.

$$
\begin{aligned}
& \operatorname{LnW}=a_{0}+a_{1} E_{s}{ }^{r}+a_{2} E_{s}{ }^{o}+a_{3} E_{s}{ }^{u}+a_{4} X+e \\
& \operatorname{LnW}=b_{0}+b_{1} E_{j}^{r}+b_{2} E_{j}{ }^{o}+b_{3} E_{j}^{u}+b_{4} X+e \\
& \operatorname{LnW}=c_{0}+c_{1} E_{m}{ }^{r}+c_{2} E_{m}{ }^{o}+c_{3} E_{m}{ }^{u}+c_{4} X+e
\end{aligned}
$$


It is assumed that the parameter estimates for required education and for overeducation are positive (in which those for required education are greater than those for overeducation), and that the parameter estimates for undereducation are negative.

The difference between self-report and the job-analyst method may then pertain to three separate aspects. There may be a difference in constants $\left(a_{0}\right.$ and $b_{0}$ respectively), there may be a difference in the slope (the parameters $a_{1}, a_{2}$ and $a_{3}$ versus $b_{1}, b_{2}$ and $b_{3}$ respectively), and there may be a difference in explanatory power (which is reflected in the explained variance). Should one of the methods systematically over- or underestimate the required level of education by one year, then this will be reflected in differences with regard to the constant and the parameter estimates of overeducation and undereducation. However, there will be no difference in the explained variance. If the measurement instruments show a substantially different degree of reliability, this will result in a difference with regard to the explained variance.

If the two instruments differ especially with regard to the standard points in which there is overeducation or undereducation, this may be caused either by the one instrument overestimating the level of overeducation or by the other instrument underestimating the level of overeducation (or both). Therefore, a number of wage equations are estimated again in stage 4, but this time with dummy values for overeducation (OE) and undereducation (UE). The attained level of education (in years) is now taken as a basis and to serve as a predictor instead of the required level of education (cf. Cohn and Khan, 1995).

In formula:

$$
\begin{aligned}
& \operatorname{LnW}=a_{0}+a_{1} E+a_{2} O E_{s}+a_{3} U E_{s}+a_{4} X+e \\
& L n W=b_{0}+b_{1} E+b_{2} O E_{j}+b_{3} U E_{j}+b_{4} X+e \\
& L n W=c_{0}+c_{1} E+c_{2} O E_{m}+c_{3} U E_{m}+c_{4} X+e \\
& L n W=d_{0}+d_{1} E+d_{2} O E_{s}+d_{3} O E_{j}+d_{4} U E_{s}+d_{5} U E_{j}+e \\
& \operatorname{LnW}=f_{0}+f_{1} E+f_{2} O E_{m}+f_{3} O E_{j}+f_{4} U E_{m}+f_{5} U_{j}+e
\end{aligned}
$$

It is now assumed that when $E_{s}^{r}$ and $E_{j}^{r}$ measure the same concept and $O E_{j}$ overestimates the level of overeducation, $b_{2}$ will be smaller than $a_{2}$ (after all, $\mathrm{OE}_{\mathrm{j}}$ will measure a great deal of noise in this case). In addition, in an equation in which the two dummy variables have been incorporated (equation 9), $\mathrm{OE}_{\mathrm{j}}$ will have no additional effect in comparison with $\mathrm{OE}_{\mathrm{s}}$. However, if $\mathrm{OE}_{\mathrm{s}}$ underestimates the level of overeducation, there will be an additional effect in equation 9 with regard to $\mathrm{OE}_{\mathrm{j}}$. 


\section{Data}

Two different data sets were used for the analysis: RUBS (Registration of the Outflow and Destination of School-leavers) and HBO-Monitor (Higher Vocational Education Monitor). The RUBS study is a representative survey among school-leavers from secondary education, i.e. General Secondary Education (GSE), Preparatory Vocational Education (PVE) and (Short) Intermediate Vocational Education (SIVE and IVE). The survey takes place within a year after graduation by means of a written questionnaire. The second study is the HBO Monitor, a study comparable to RUBS among graduates of Higher Vocational Education. The latter survey takes place just over a year after graduation ${ }^{4}$. For the current analysis, the surveys among graduates of the academic year 1991 - 1992 were used, which took place in 1993. The two sets were linked and weighted on the basis of national data. See Van Smoorenburg et al. (1994) and Van de Loo and Van der Velden (1994) for a more detailed description of the data sets.

For the analysis, a selection was made from this linked set. We selected graduates from fulltime courses in 1991 - 1992 (part-time education has not been considered). Furthermore, school-leavers from General Secondary Education (GSE) have been left out, because only 5\% of the graduates in this category enter the labour market and hence GSE does not serve as final education. In addition, only those who had paid work at the moment of the survey have been selected. Respondents over the age of 27 or under the age of 16 have also been left out of the analysis.

\section{Results}

In Table 1, the percentages of over- and undereducation according to the self-report method have been indicated per level of education.

Table 1

Overeducation, adequate education and undereducation among school-leavers by level of education, according to the self-report method

\begin{tabular}{lcccc}
\hline & $\begin{array}{c}\text { Undereducation } \\
\%\end{array}$ & $\begin{array}{c}\text { Adequate education } \\
\%\end{array}$ & $\begin{array}{c}\text { Overeducation } \\
\%\end{array}$ & $\begin{array}{c}\text { weighed } \\
\text { N }(=100 \%)\end{array}$ \\
\hline PVE & 16 & 75 & 9 & 10,600 \\
SIVE & 25 & 8 & 67 & 5,900 \\
IVE & 1 & 79 & 20 & 24,800 \\
HVE & 3 & 78 & 31 & 15,000 \\
Total & 7 & 70 & 23 & 56,300
\end{tabular}

4. As from 1995, both studies are executed according to an integrated model. 
Across the board, $70 \%$ of the respondents indicate that they hold a position for which their own level of education was required (adequately educated). Nearly a quarter holds a position for which a lower level of education is required (overeducated) and $7 \%$ hold a position for which a higher level of education is required (undereducated). For IVE and HVE, the patterns are almost similar: one in five graduates is overeducated and hardly anyone is undereducated. In PVE, the percentage of undereducated people is considerably higher, which can be explained by the fact that of these school-leavers many move on to an apprenticeship. The required level of education as indicated by these respondents reflects the situation at the end of the apprenticeship rather than the requirements upon moving on to the apprenticeship. SIVE clearly takes up a unique position. Only $8 \%$ of the respondents indicate that they are adequately trained and $67 \%$ hold a position for which a maximum level of PVE suffices. These figures clearly reflect the fact that SIVE is not yet appreciated as a recognisable level by employers.

\section{Table 2}

Overeducation, adequate education and undereducation among school-leavers by level of education, according to the job-analyst method.

\begin{tabular}{lcccc}
\hline & $\begin{array}{c}\text { Undereducation } \\
\%\end{array}$ & $\begin{array}{c}\text { Adequate education } \\
\%\end{array}$ & $\begin{array}{c}\text { Overeducation } \\
\%\end{array}$ & $\begin{array}{c}\text { weighed } \\
\mathrm{N}(=100 \%)\end{array}$ \\
\hline PVE & 38 & 24 & 38 & 11,000 \\
SIVE & 1 & 31 & 68 & 6,300 \\
IVE & 2 & 17 & 81 & 25,300 \\
HVE & 6 & 37 & 57 & 15,300 \\
Total & 10 & 25 & 65 & 57,900 \\
\hline
\end{tabular}

Table 2 shows the percentages of overeducation and undereducation according to the jobanalyst method per level of education. The most important difference between the two methods pertains to the substantial increase of the number of overeducated people. This percentage rises from $23 \%$ to $65 \%$. This increase occurs on all levels of education, albeit not to the same extent in all cases. Especially in the case of IVE, the increase in the number of overeducated people is very substantial: the percentage has risen from $20 \%$ to $81 \%$. The increase in the number of undereducated people at PVE-level is remarkable as well. This is related with the aforementioned continuation into apprenticeships and the fact that no distinction is made between the status of apprentice and that of skilled worker in the classification of occupations.

The difference between the two methods is also clear when the required number of years of education is considered. In the self-report method, the average number is 13.2 years, whereas the average number of years required according to the job-analyst method is 11.4 years. In 
other words, according to the job-analyst method, the required number of years of education for school-leavers from vocational education is nearly 2 years lower than that of the self-report method.

Of course, the question is whether this is simply a systematic difference between the two methods when it comes to the number of years of required education or whether they measure different concepts. In order to determine this, we have calculated the correlation between the two $\left(E_{s}^{r}\right.$ and $\left.E_{j}^{r}\right)$ in stage 2. This correlation is 0.66 , which is not very high, considering that both instruments intend to measure the same concept. After all, the common variance is only $43 \%$. This can partly be explained by the variance in educational requirements which exist within one and the same occupation. These differences are picked up by the self-report method, but not, by definition, by the job-analyst method. In order to estimate the scope of this aggregation effect, the correlation with the average self-report determined per occupation $\left(E_{m}{ }^{2}\right)$ has also been calculated. In this case, the correlation with the job-analyst method $\left(E_{j}^{r}\right)$ is 0.78 , which indicates that some of the differences between the two methods are in fact related with the level of aggregation. The common variance is now $61 \%$.

Do the established differences between the two methods also lead to a difference in explanatory power? Table 3 presents the results of the wage equations carried out in stage 3. The first column concerns the wage equation based on the self-report method (equation 3), the second column is based on the job-analyst method (equation 4) and the third column on the average self-report per occupation (equation 5). Four control variables on sex, ethnicity (dummy), age (in years) and the region in which the person is employed and two dummy variables indicating whether the own field of education or, conversely, a completely different field of education was required for the job concerned (reference category: no specific field of education required) were included.

The return of one additional year of required education is about $7 \%$, which corresponds well with similar estimates elsewhere in the literature (see e.g. Hartog and Jonker, 1997). As expected, the return of one year of overeducation is slightly lower, namely $5 \%$. As was also expected, the return of undereducation is negative and is 7 to $9 \%$, depending on the measurement instrument.

With regard to this analysis, it is important to note that the estimates for the constant and the parameter estimates for the $E^{r}$ variables do not differ significantly for the three different methods. For all three equations, the parameter estimate for the number of years of required education is virtually identical, namely 0.067 . The estimates of the effects of overeducation and undereducation do differ, however. The $95 \%$-confidence interval for $E_{s}{ }^{\circ}$ is between 0.042 and 0.051 . For $E_{j}^{0}$ this confidence interval is between 0.050 and 0.058 . Therefore, the parameters found for the job-analyst method do not fall within the confidence interval of the self-report method and vice versa. The same goes for the estimates with regard to the effect of undereducation. In this case, the $95 \%$-confidence interval of $E_{s}{ }^{u}$ is between -0.082 and 0.058 , whereas for $E_{j}{ }_{j}^{u}$ it is between -0.101 and -0.081 . 
The three methods do not differ significantly when it comes to explanatory power. The adjusted $\mathrm{R}^{2}$ is $59 \%$ for the self-report method and $58 \%$ for the job-analyst method. In equation 5 , the adjusted $R^{2}$ is also $58 \%$.

We may therefore conclude that the effect of one year of required education according to the self-report method does not differ significantly from the effect of one year of required education according to the job-analyst method. The effects of one year of overeducation and one year of undereducation respectively, however, do differ significantly from one method to the other.

Table 3

Wage equations based on three different measurements of the required level of education and the level of overeducation and undereducation (equations 3,4 and 5).

\begin{tabular}{|c|c|c|c|c|c|c|}
\hline & \multicolumn{2}{|c|}{$\begin{array}{l}\text { Self-report per function } \\
\text { (equation 3) }\end{array}$} & \multicolumn{2}{|c|}{$\begin{array}{l}\text { Job-analyst method } \\
\text { (equation 4) }\end{array}$} & \multicolumn{2}{|c|}{$\begin{array}{l}\text { Average self-report } \\
\text { per occupation } \\
\text { (equation } 5 \text { ) }\end{array}$} \\
\hline & coefficient & $\begin{array}{l}\text { standard } \\
\text { error }\end{array}$ & coefficient & $\begin{array}{l}\text { standard } \\
\text { error }\end{array}$ & coefficien & $\begin{array}{l}\text { th standard } \\
\text { error }\end{array}$ \\
\hline Required level of education $E^{r}$ & $0.067^{* *}$ & 0.002 & $0.067^{* *}$ & 0.002 & $0.066^{* *}$ & 0.002 \\
\hline Overeducation $\mathrm{E}^{\circ}$ & $0.047^{* *}$ & 0.002 & $0.054^{* *}$ & 0.002 & $0.047^{* *}$ & 0.002 \\
\hline Undereducation $\mathrm{E}^{\mathrm{u}}$ & $-0.070^{\star \star}$ & 0.006 & $-0.091^{\star \star}$ & 0.005 & $-0.084^{* *}$ & 0.005 \\
\hline \multicolumn{7}{|l|}{ Control variables } \\
\hline Female & $-0.014^{\star \star}$ & 0.006 & $-0.019^{* *}$ & 0.006 & $-0.019^{\star *}$ & 0.006 \\
\hline Non-Dutch & -0.039 & 0.021 & $-0.050^{*}$ & 0.021 & $-0.050^{*}$ & 0.021 \\
\hline Age & $0.052^{\star *}$ & 0.002 & $0.051^{\star *}$ & 0.002 & $0.052^{* *}$ & 0.002 \\
\hline North & $-0.064^{* *}$ & 0.011 & $-0.068^{\star *}$ & 0.011 & $0.065^{\star *}$ & 0.011 \\
\hline East & $-0.027^{* *}$ & 0.007 & $-0.026^{\star *}$ & 0.007 & $-0.025^{\star *}$ & 0.007 \\
\hline West & ref. & & ref. & & ref. & \\
\hline South & $-0.026^{\star *}$ & 0.006 & $-0.027^{\star *}$ & 0.006 & $-0.024^{* *}$ & 0.006 \\
\hline Foreign countries & $0.111^{* *}$ & 0.018 & $0.109^{\star *}$ & 0.018 & $0.113^{\star \star}$ & 0.018 \\
\hline \multicolumn{7}{|l|}{ Required educational field } \\
\hline Own discipline & $0.044^{* *}$ & 0.006 & $0.064^{\star *}$ & 0.006 & $0.062^{* *}$ & 0.006 \\
\hline Other discipline & -0.008 & 0.013 & 0.007 & 0.014 & 0.006 & 0.014 \\
\hline No discipline & ref. & & ref. & & ref. & \\
\hline Constant & $0.449^{\star \star}$ & 0.026 & $0.486^{\star *}$ & 0.027 & $0.444^{\star *}$ & 0.026 \\
\hline Number of cases & & 10,072 & & ,218 & 10,2 & \\
\hline Adjusted $\mathrm{R}^{2}$ & & 0.592 & & 0.581 & & 0.582 \\
\hline
\end{tabular}

${ }^{*}$ Significant to $1 \%{ }^{*}$ Significant to $5 \%$

This outcome may be interpreted as follows. Both the job-analyst method and the self-report 
method essentially measure the same concept, namely the number of years of education required. However, they differ considerable in determining the standard points, the points on the scale at which there is overeducation, adequate education and undereducation. According to the job-analyst method, $65 \%$ of the population is "overeducated", whereas the rate of overeducation is no higher than $23 \%$ according to the self-report method. Which method is closest to the "true" score for the level of overeducation?

In order to establish this, five new wage equations have been estimated in stage 4, this time with the level of education actually attained (in years), and with dummy variables for overeducation (OE) and undereducation (UE). These analyses reflect the equations (6) - (10), respectively. The control variables from the equations in Table 3 have also been incorporated to serve as predictors.

If the level of overeducation is systematically overestimated in the job-analyst method, this will be reflected by a less negative parameter estimate for $\mathrm{OE}_{\mathrm{j}}$, in equation 7 . In addition, in equation 9 , where both measurement instruments have been incorporated, $\mathrm{OE}_{\mathrm{j}}$ will no longer have an additional effect in comparison with $\mathrm{OE}_{s}$. However, if the self-report method underestimates the level of overeducation, there will be an additional effect with regard to $O E_{j}$ in equation 9 which includes both dummy variables.

\section{Table 4}

Wage equations with dummy variables for overeducation and undereducation (standard errors between brackets).

Equation $6 \quad$ Equation $7 \quad$ Equation $8 \quad$ Equation 9 Equation 10

\begin{tabular}{|c|c|c|c|c|c|}
\hline Level of education attained $\mathrm{E}$ & $\begin{array}{l}0.066^{\star *} \\
(0.002)\end{array}$ & $\begin{array}{l}0.064^{* *} \\
(0.002)\end{array}$ & $\begin{array}{l}0.053^{* *} \\
(0.002)\end{array}$ & $\begin{array}{l}0.066^{\star *} \\
(0.002)\end{array}$ & $\begin{array}{c}0.063^{\star *} \\
(0.002)\end{array}$ \\
\hline $\mathrm{UE}_{\mathrm{s}}$ & $\begin{array}{l}-0.022 \\
(0.014)\end{array}$ & & & $\begin{array}{l}-0.021 \\
(0.014)\end{array}$ & \\
\hline $\mathrm{OE}_{\mathrm{s}}$ & $\begin{array}{l}-0.095^{\star *} \\
(0.006)\end{array}$ & & & $\begin{array}{l}-0.096^{* *} \\
(0.006)\end{array}$ & \\
\hline $\mathrm{UE}_{\mathrm{j}}$ & & $\begin{array}{l}-0.059^{* *} \\
(0.012)\end{array}$ & & $\begin{array}{l}-0.059^{* *} \\
(0.012)\end{array}$ & $\begin{array}{l}-0.057^{\star *} \\
(0.012)\end{array}$ \\
\hline$O E_{j}$ & & $\begin{array}{l}-0.022^{* *} \\
(0.006)\end{array}$ & & $\begin{array}{l}-0.009 \\
(0.005)\end{array}$ & $\begin{array}{l}-0.003 \\
(0.007)\end{array}$ \\
\hline $\mathrm{UE}_{\mathrm{m}}$ & & & $\begin{array}{l}-0.092^{* *} \\
(0.015)\end{array}$ & & $\begin{array}{l}-0.081^{\star *} \\
(0.016)\end{array}$ \\
\hline $\mathrm{OE}_{\mathrm{m}}$ & & & $\begin{array}{l}-0.070^{* *} \\
(0.006)\end{array}$ & & $\begin{array}{l}-0.073^{* *} \\
(0.006)\end{array}$ \\
\hline \multicolumn{6}{|l|}{ Control variables ${ }^{5}$ ) } \\
\hline Number of cases & 10.072 & 10.218 & 10.213 & 10.072 & 10.213 \\
\hline
\end{tabular}


Adjusted $\mathrm{R}^{2}$

Model improvement:

Difference between parameters:
Eq. 9 - Eq. 6: $F=12.96 \mathrm{df}=2 \mathrm{p}<.01$

Eq. 9 - Eq. 7: $F=434.06 \mathrm{df}=2 \mathrm{p}<.01$

Eq. 10 - Eq. 7: $F=89.27 \mathrm{df}=2 \mathrm{p}<.01$

Eq. 10 - Eq. 8: $F=23.13 \mathrm{df}=2 p<.01$

Eq. 9: $U E_{s}-U E_{j}: t=2.13^{\star \star}$

Eq. 9: $\mathrm{OE}_{\mathrm{s}}-\mathrm{OE}: \mathrm{t}=-10.43^{\star *}$

Eq. 10: $U E_{m}-U E_{h}: t=-1.30$

Eq. 10: $O E_{m}-O E_{h}: t=-9.31^{* *}$

${ }^{* *}$ significant to $1 \%$

Table 4 lists the most important results of this analysis. Equation 6 displays the equation with dummy variables for overeducation and undereducation according to the self-report method. The effect of undereducation does not deviate significantly from zero. The effect of overeducation leads to a negative income effect of nearly $10 \%$ in comparison with schoolleavers who are in fact employed in a job which matches with their level of education. Equation 7 provides the results for the job-analyst method. Contrary to the expectations, the effect of undereducation is a negative one. Van Smoorenburg and Van der Velden (1996) have shown that this has to do primarily with the loss of income which results from taking a course within the apprenticeship system ${ }^{6}$. What is important here is that the negative effect of overeducation is only -0.022 . If we combine these in one equation (equation 9), it appears that the parameter estimates for $\mathrm{OE}_{\mathrm{s}}$ and $\mathrm{OE}_{\mathrm{j}}$ differ significantly. This leads to the conclusion that the level of overeducation, when determined by means of the job-analyst method, is severely overestimated, whereas the level of overeducation according to the self-report method is not underestimated.

The differences between the two methods cannot be attributed to a difference in the level of aggregation. After all, even when the level of overeducation is determined on the basis of the average self-report per occupation (equation 8), there is still a significant difference in the magnitude of the parameter estimates, although the difference becomes somewhat smaller. In equation 8 , the estimate for $\mathrm{OE}_{m}$ is -0.070 , which is nearly three times the estimate for $\mathrm{OE}_{\mathrm{j}}$. Here, too, the effect of $\mathrm{OE}_{\mathrm{j}}$ is no longer significant when both dummy variables are incorporated in the same equation (equation 10).

\section{Conclusion}

In this article, we have examined the criterion validity of two different methods for determining the level of required education for a particular job, namely: the self-report method, in which the

6. Graduates from VBO, who take a course in the apprenticeship system often regard themselves as undereducated. Because these types of training can be regarded as generic with benefits for the employee rather than for the employers, following this type of training is accompanied by a loss of income. 
workers themselves indicate the level of education minimally required for the job they hold, and the job-analyst method, in which experts express their opinion about the minimum level of education required for a given job.

When applied to the position of school-leavers on the Dutch labour market, the two methods appear to differ significantly, both with regard to the average level of required education and with regard to the level of overeducation and undereducation. According to the self-report method, the average level of education required is 13.2 years and $23 \%$ of school-leavers have a job below their own level of education. According to the job-analyst method, the average level of education required is 11.4 years and as much as $65 \%$ of the school-leavers is "overeducated".

The main conclusion is that the two methods measure essentially the same concept (number of years of required education). However they differ significantly with regard to the standard points, i.e. the points on the scale at which there is overeducation and undereducation. The analysis shows that the job-analyst method systematically overestimates the level of overeducation. There are no indications that the level of overeducation is underestimated in the self-report method. Therefore, the conclusion must be that the self-report method yields a considerably more accurate estimate of the level of education required than the job-analyst method.

\section{Literature}

Barron, J.M., D.A. Black and M.A. Loewenstein (1989), Job Matching and On-The-Job Training, Journal of Labor Economics, vol. 7, pp. 1-19.

Clogg, C.C. \& J.W. Shockey (1984), Mismatch between Occupation and Schooling: A Prevalence Measure, Recent Trends and Demographic Analysis, Demography, 21, pp. 235-257.

Cohn, E. \& S.P. Khan (1995), The Wage Effects of Overschooling Revisited, Labour Economics 2, pp. 67-76.

Dekker, R., A. de Grip, H. Heijke (1996), The Effects of Training and Overeducation on Career Mobility in a Segmented Labour Market, ROA-RM-1996/4E.

Duncan, G. \& S. Hoffman (1981), The Incidence and Wage Effects of Overeducation, Economics of Education Review, 1, pp. 75-86.

Groot, W. (1993), Overeducation and the Returns to Enterprise-related Schooling, Economics of Education Review, 13, pp. 299-309.

Groot, W. and H. Maassen van den Brink (1996), Overscholing en verdringing op de arbeidsmarkt (Overeducation and Displacement on the Labour Market), Economisch Statistische Berichten, 24-11996, pp. 44-74.

Halaby, C.N., Overeducation and Skill Mismatch, Sociology of Education, 67, 1, pp. 47-59.

Hartog, J. \& H. Oosterbeek (1988), Education, Allocation and Earnings in the Netherlands: Over 
schooling?, Economics of Education Review, 7, no. 2, pp. 185-194.

Hartog, J. \& N. Jonker (forthcoming), A Job to Match your Education: Does it Matter? To appear in: Heijke, H. and L. Borghans (eds.) (forthcoming), Towards a Transparent Labour Market for Educational Decisions, Avebury.

Hersch, J. (1991), Education Match and Job Match, Review of Economics and Statistics 37, pp. 140-144. Huijgen, F. (1989), De kwalitatieve structuur van de werkgelegenheid in Nederland ("The Qualitative Structure of Employment in The Netherlands"), part III, Bevolking in loondienst en functiestructuur in 1977 en 1985 ("Population in Paid Employment and Function Structure in 1977 and 1985"), Organisatie voor Strategisch Arbeidsmarktonderzoek (Organisation for Strategic Labour Market Research), Preliminary study OSA-V33, The Hague, The Netherlands.

Loo, P.J.E. van de, and R.K.W. van der Velden (1994), De arbeidsmarktpositie van afgestudeerden van het hoger beroepsonderwijs ("The Labour Market Position of Higher Vocational Education Graduates"), HVE Monitor 1993. The Hague: HBO-Raad (HVE Council).

Sicherman, N. (1991), "Overeducation" in the labour market, Journal of Labor Economics, Volume 9, Number 2, pp. 101-122.

Smoorenburg, M.S.M. van, R.K.W. van der Velden, P.J.E. van de Loo \& M.H. Wieling (1994), School verlaters op de arbeidsmarkt, de uitstroom en bestemming van het schooljaar 1991-1992 ("Schoolleavers on the Labour Market, the Outflow and Destination of the Academic Year of 1991-1992"), Leeuwarden, The Netherlands, Stichting Landelijk Dienstverlenend Centrum voor Studie- en Beroepskeuzevoorlichting (National Service Centre for Information on the Choice of Education and Occupation).

Smoorenburg, M.S.M. van, R.K.W. van der Velden (1996), The Training of School-leavers, ROA-RM1996/5E.

Tsang, M.C., R.W. Rumberger and H.M. Levin (1991), The Impact of Surplus Schooling on Worker Productivity, Industrial Relations 30, no. 2, pp. 209-228.

Velden, R.K.W. van der (1991), Sociale herkomst en schoolsucces ("Social Background and School careers). PhD Thesis, Groningen, The Netherlands: RION.

Verdugo, R.R. and N.T. Verdugo (1989), The Impact of Surplus Schooling on Earnings, Journal of Human Resources, 24, 4, pp. 629-643. 